\title{
PERENCANAAN INDUSTRI ROTI KAFFAH DI KABUPATEN BANTAENG, SULAWESI SELATAN
}

\author{
Oleh: \\ Wildan Wibawa Perdana, ST.,MT. \\ wildan.w.perdana@gmail.com \\ Fakultas Teknologi Pertanian Universitas Al-Ghifari
}

\begin{abstract}
Abstrak
Bupati Kabupaten Bantaeng, Nurdin Abdullah menyampaikan kondisi Kabupaten Bantaeng sebagai salah satu wilayah yang kecil di Sulawesi Selatan, hanya memiliki luas $395,83 \mathrm{~km}^{2}$. Makassar sedang mengalami pertumbuhan ekonomi yang sangat pesat. Pertumbuhan ekonomi di Makassar pada tahun 2009 tercatat sebesar $9.20 \%$ dan pada tahun 2013 meningkat menjadi $9.88 \%$. Peningkatan ini didominasi 5 sektor yaitu sektor hotel dan restoran sebesar $29.6 \%$, industri pengolahan $17.51 \%$, angkutan dan komunikasi $15.73 \%$, sektor jasa $15.67 \%$, dan keuangan $11.61 \%$ (Yudhatama, 2014). Industri bakery di Indonesia mengalami pertumbuhan yang cukup signifikan pada beberapa tahun terakhir. Menurut data Euromonitor, nilai konsumsi roti per kapita oleh masyarakat Indonesia pada 2010 tumbuh tertinggi dibandingkan 11 negara Asia Pasifik lainnya. Nilai konsumsi roti di Indonesia naik $25 \%$ pada 2010 menjadi US $\$ 1,5$ per orang per tahun, dari data tersebut dapat disimpulkan bahwa perusahaan-perusahaan bakery di Indonesia mempunyai peluang yang bagus dalam meraih profit di dalam industri bakery.

Maksud dan tujuan dari penelitian ini adalah mempelajari perencanaan dan merancang mesin alat pada proses pembuatan roti sehingga produk yang dihasilkan aman bagi konsumen dan tercipta lingkungan industri yang nyaman bagi para pegawai dan mengurangi jumlah penganguran daerah setempat. Pada proses perencanaan dan rancang bangun industri roti ini dilakukan dengan beberapa tahapan antara lain : Survei Lapangan, Analisis Data, Perhitungan Perencanaan dan Rancang Bangun Peralatan Industri Roti, Gambar Perencanaan dan Rancang Bangun Yang Dirancang, Revisi Gambar, Proses Perancangan Keseluruhan, Perakitan Alat Di Workshop, Uji Coba Alat, dan Proses Receive Dan Reject.

Berdasarkan hasil proses perencanaan dan rancang bangun industri roti ini dapat disimpulkan bahwa perencanaan flowsheet proses berpengaruh terhadap penggunaan maksimal kapasitas mesin, kecepatan proses pengolahan dan hasil produk yang lebih terjamin keamanannya. Perancangan tata letak proses pengolahan juga berpengaruh terhadap penggunaan maksimal kapasitas mesin, kecepatan proses pengolahan dan hasil produk yang lebih terjamin keamanannya. dan Berdasarkan hasil pengujian produk yang dihasilkan lebih cepat dan aman serta pengawasan mudah dilakukan.
\end{abstract}

Kata kunci : Makasar, Rancang bangun, Indutri roti.

\begin{abstract}
Bantaeng District Head Nurdin Abdullah said that the condition of Bantaeng Regency as a small area in South Sulawesi had an area of $395.83 \mathrm{~km} 2$. Makassar experienced very fast economic growth. Economic growth in Makassar in 2009 was recorded at 9.20\% and in 2013 it increased to 9.88\%. This increase was dominated by 5 sectors, namely the hotel and restaurant sector by 29.6\%, processing industry $17.51 \%$, transportation and communication $15.73 \%$, sector services $15.67 \%$, and finance $11.61 \%$
\end{abstract}

Perencanaan Industri Roti Kaffah di

WILDAN WIBAWA PERDANA

Kabupaten Bantaeng, Sulawesi Selatan 
(Yudhatama, 2014 ) The bread industry in Indonesia has experienced significant growth in recent years. According to Euromonitor data, the value of bread consumption per capita by Indonesians in 2010 grew the highest compared to 11 other Asia Pacific countries. The value of bread consumption in Indonesia rose 25\% in 2010 to US $\$ 1.5$ per person per year, from the data it can be concluded that bakeries in Indonesia have a good chance of making a profit in the bakery industry.

The purpose and objective of this study is to study planning and design machine the bread making process so that the products produced are safe for consumers and create a comfortable industrial environment for employees and reduce the amount of unemployment in the local area.In the planning and design process of the bakery industry it is carried out in several stages including: Field Survey, Data Analysis, Calculation of Planning and Designing of Bread Industry Equipment, Image Design and Design Planning, Image Revision, Overall Design Process, Assembly of Tools in the Workshop, Test Tools, and Receive and Reject Processes.

Based on the results of the planning and design process of the bread industry, it can be concluded that the process flowheet process affects the maximum use of engine capacity, the speed of processing and the results of products that are more secure.Process layout design also affects the maximum use of engine capacity, and Based on the results of product testing the results are faster, safer and supervision is easy to do.

Keywords: Makassar, Bantaeng, industrial design, and bread industrial. 


\section{PENDAHULUAN}

Bupati Kabupaten Bantaeng, Nurdin Abdullah menyampaikan kondisi Kabupaten Bantaeng sebagai salah satu wilayah yang kecil di Sulawesi Selatan, hanya memiliki luas $395,83 \mathrm{~km}^{2}$. Pada saat ini, Makassar sedang mengalami pertumbuhan ekonomi yang sangat pesat. Pertumbuhan ekonomi di Makassar pada tahun 2009 tercatat sebesar $9.20 \%$ dan pada tahun 2013 meningkat menjadi $9.88 \%$. Peningkatan ini didominasi 5 sektor yaitu sektor hotel dan restoran sebesar 29.6\%, industri pengolahan $17.51 \%$, angkutan dan komunikasi $15.73 \%$, sektor jasa $15.67 \%$, dan keuangan 11.61\% (Yudhatama, 2014). Dengan pertumbuhan ekonomi di Makassar yang sangat pesat ini, wajar kalau nantinya persaingan akan semakin ketat yang akan berdampak pada laba. Sehingga untuk mencegah hal itu terjadi, pengusaha harus melakukan perubahan yang cepat dan tepat dalam hal strateginya untuk menghadapi pesaing-pesaingnya. (Ong Kevin, 2015).

Industri bakery di Indonesia mengalami pertumbuhan yang cukup signifikan pada beberapa tahun terakhir. Menurut data Euromonitor, nilai konsumsi roti per kapita oleh masyarakat Indonesia pada 2010 tumbuh tertinggi dibandingkan 11 negara Asia Pasifik lainnya. Nilai konsumsi roti di Indonesia naik 25\% pada 2010 menjadi US $\$ 1,5$ per orang per tahun, dari konsumsi US $\$ 1,2$ per orang per tahun pada 2009. Pertumbuhan itu menjadi yang tertinggi dibanding kenaikan nilai konsumsi roti di negaranegara seperti Korea Selatan, Singapura, China, Taiwan, dan India pada periode yang sama. Dari data tersebut dapat disimpulkan bahwa perusahaan-perusahaan bakery di Indonesia mempunyai peluang yang bagus dalam meraih profit di dalam industri bakery. '

Meningkatnya persaingan industri yang semakin maju mengakibatkan persaingan bisnis semakin ketat, sehingga setiap perusahaan akan bersaing dalam memberikan pelayanan yang memuaskan bagi pelanggannya. Sangat penting bagi perusahaan untuk merencanakan operasional produksi dengan tepat supaya dapat meminimalisir biaya-biaya yang diperlukan untuk kegiatan produksi.

Perusahaan-perusahaan bergerak dibidang yang sama akan berusaha untuk meningkatkan kualitas produk dan pelayanannya supaya dapat bertahan dan bersaing di dalam industri. Ini merupakan ancaman bagi perusahaan pendatang baru maupun pemain lama karena akan berdampak pada profit yang dihasilkan.

Perusahaan tidak mengalami penurunan profit dan dapat bertahan pada bisnis yang sedang berjalan diperlukan cara yang tepat untuk mengalahkan pesaingnya salah satunya dengan cara melakukan peramalan penjualan dari produk yang dihasilkan. Perusahaan dapat meminimalisir harga dengan mengendalikan biaya produksi agar memperoleh laba yang optimal. Biaya produksi dapat dikendalikan perusahaan dengan cara melakukan peramalan penjualan produk pada periode berikutnya untuk dijadikan dasar pengambilan keputusan dalam menentukan persediaan bahan baku. Biaya lain yang berkaitan dengan operasional produksi seperti biaya pasokan bahan baku, dimana untuk memasok bahan baku, perusahaan harus mengeluarkan sejumlah biaya pengiriman agar bahan baku dapat diterima perusahaan dengan tepat waktu. Perusahaan harus mempertimbangkan dengan tepat biaya pemasokan bahan baku agar tidak mengeluarkan biaya pengiriman bahan baku dari supplier ke perusahaan secara berlebihan. Biaya pemasokan bahan baku berupa biaya pengiriman yang telah diminimalisir dapat dialokasikan untuk keperluan biaya lainnya oleh perusahaan.

Peramalan penjualan dapat digunakan sebagai dasar pengambilan keputusan bagi perusahaan untuk 
mencapai profit yang maksimal dan sebagai dasar perencanaan produksi agar tidak terjadi over production yang mengakibatkan stok barang menumpuk maupun under production yang mengakibatkan perusahaan kehilangan kesempatan dalam menjual produknya. Hasil dari peramalan penjualan berguna bagi perusahaan untuk merencanakan biaya-biaya yang dibutuhkan dalam melakukan kegiatan produksi maupun biaya-biaya lainnya di dalam perusahaan.

Biaya produksi berhubungan dengan persediaan bahan baku yang dibutuhkan dalam melakukan proses produksi. Perusahaan harus cermat dalam hal persediaan bahan baku supaya tidak terjadi hambatan saat kegiatan produksi dilakukan. Persediaan bahan baku yang tidak cermat dapat mengakibatkan produksi tidak dapat berjalan dengan lancar dan dihasilkan tidak tepat pada waktunya. Sebaliknya, persediaan bahan baku yang berlebihan mengakibatkan pembengkakan biaya persediaan di dalam kegiatan produksi. Apabila hal itu terjadi, perusahaan akan mengalami kerugian seperti profit yang dihasilkan tidak mencapai target dan pelanggan akan berpindah ke perusahaan lain karena tidak mendapatkan pelayanan yang memuaskan dari perusahaan. Agar proses produksi dapat berjalan dengan baik, manajer yang bertanggung jawab pada bagian persediaan harus mengatur dan menetapkan secara tepat kebutuhan bahan baku yang akan digunakan dalam melakukan produksi supaya tidak terjadi kelebihan maupun kekurangan persediaan pada saat produksi dilakukan. Untuk mengatasi masalah tersebut, maka diperlukan cara yang tepat bagi perusahaan dalam mengontrol persediaan bahan bakunya.

$$
\text { Persediaan bahan baku }
$$

merupakan komponen dasar bagi perusahaan manufaktur untuk melakukan produksi. Namun, yang sering terjadi di perusahaan pada umumnya adalah kesulitan dalam memperkirakan permintaan pelanggan pada periode berikutnya sehingga bahan baku yang tersedia tidak mencukupi permintaan pelanggan terhadap jumlah produk yang dihasilkan perusahaan. Persediaan bahan baku baik dalam keadaan kekurangan maupun kelebihan membawa dampak buruk bagi perusahaan karena akan berpengaruh pada pengeluaran biaya yang besar oleh perusahaan.

Dari latar belakang masalah yang ada, dapat diidentifikasikan bagaimana membuat perencanaan dan rancang bangun industri roti dengan bahan pertimbangan penggunaan bahan utama dan penunjang dari awal proses sampai dengan selesai sehingga dihasilkan produk yang maksimal aman bagi karyawan dan konsumen.

Maksud dan tujuan dari penelitian ini adalah mempelajari perencanaan dan merancang mesin alat pada proses pembuatan roti sehingga produk yang dihasilkan aman bagi konsumen dan tercipta lingkungan industri yang nyaman bagi para pegawai dan mengurangi jumlah penganguran daerah setempat.

Manfaat penelitian ini adalah dengan harapan agar perencanaan dan rancang bangun industri roti yang aman dan efisien dapat diterapkan di industri menengah kecil sehingga produk yang dihasilkan tidak kalah dengan produk buatan pabrik besar dan menurunkan tingkat pengangguran didaerah setempat.

\section{Kerangka Penelitian}

Perubahan gaya hidup menjadi faktor pemicu terjadinya perubahan pola konsumsi. Dengan semakin padatnya waktu bekerja, masyarakat semakin sibuk sehingga mendorong pemilihan makanan dengan penyajian lebih praktis, tetapi beragam. Makanan tersebut harus segar sepanjang hari, penampilan menarik, aman bagi kesehatan, mengandung banyak kalori dan dapat memberikan nilai gizi yang dibutuhkan oleh tubuh.

Pemilihan akan bahan pangan cenderung berubah seiring dengan 
perkembangan social-ekonomi masyarakat dunia. Untuk negara-negara yang sudah maju seiring dengan peningkatan pendapatan terjadi peralihan ke pemilihan bahan pangan yang mempunyai kelezatan yang lebih tinggi, yaitu perubahan dari makanan yang kebanyakan serealia ke makanan yang banyak mengandung protein hewani. Namun, untuk negara-negara yang sedang berkembang dimana penduduknya masih berpenghasilan rendah, protein hewani masih sulit diperoleh karena harganya yang relatif mahal. Sehingga makanan yang banyak terdapat didaerah ini adalah makanan yang berasal dari serealia yang banyak mengandung pati.

Kecenderungan pola konsumsi yang berubah juga terjadi di Indonesia, yaitu perubahan dari konsumsi serealia hasil industri rumah tangga menjadi konsumsi serealia dari pabrik, seperti roti dan kue panggang. Hal ini disebabkan perkembangan sosial ekonomi dimana pada saat sekarang ini orang membutuhkan makanan cepat saji (fastfood) tetapi masih memenuhi akan kebutuhan gizi dan kalori. Perubahan konsumsi ini umumnya terjadi pada golongan masyarakat menengah ke atas.

Roti adalah salah satu makanan tertua di dunia. Sejarah berawal dari Mesir dan Mesopotamia. Saat mereka menemukan cara lain untuk menikmati gandum. Gandum yang awalnya dikonsumsi langsung ternyata dapat dilumat bersama air sehingga membentuk pasta. Pasta yang dimasak diatas api kemudian mengeras dan dapat disimpan beberapa hari.

Teknik paling dasar memasak roti seperti ini masih digunakan dibeberapa negara walau perkembangan teknik dan jenis roti modern semakin beragam. Sebut saja tortila Mexico, roti canai India, Pita di Timur Tengah, dan lain-lain. Roti-roti semacam ini dikenal lebih dengan nama istilah roti datar.

Ragi roti ditemukan saat mereka menyimpan sedikit adonan dari hari sebelumnya dan ditambahkan pada adonan yang baru. Kemudian dikembangkan pula jenis gandum yang baru yang memungkinkan terciptanya jenis roti yang baru. Yunani mengambil teknologi pembuatan roti dari Mesir. Teknologi yang kemudian menyebar di seluruh Eropa dan menjadikan roti sebagai makanan yang dianggap penting oleh masyarakatnya. Di Roma roti dan gandum lebih penting ketimbang daging.

Roti adalah produk makanan yang dibuat dari tepung terigu dan sangat populer dimasyarakat. Tepung terigu yang digunakan berasal dari biji gandum yang ketersediaannya diimpor. Roti merupakan produk olahan tepung yang mudah rusak, terutama akibat serangan mikroba. Mikroba yang umumnya menyebabkan kerusakan pada roti yaituMonilia spyang dapat menyebabkan timbulnya benang-benang halus pada roti dan akhirnya timbul lendir sehingga menghasilkan kerusakan pada roti. Hal tersebut menyebabkan umur simpan roti yang singkat sehingga dibutuhkan bahan pengawet yang dapat memperpanjang umur simpan.

Ilmu pangan mengartikan roti dikelompokkan dalam produk bakery,bersama dengan cake, donat, biskuit, roll, cracker, dan pie. Di dalam kelompok bakery, roti merupakan produk yang paling pertama dikenal dan paling populer dijagat raya hingga saat ini. Sama halnya seperti di belahan dunia lain, budaya makan roti juga berkembang di Indonesia. Memang, mula-mula hanya pada kelompok masyarakat tertentu. Itu pun sebatas sebagai pengganti nasi pada saat sarapan pagi, yang umumnya disajikan bersama-sama dengan telur dadar atau segelas susu.

\section{Hipotesis Penelitian}

Berdasarkan uraian pada kerangka pemikiran maka dapat dibuat hipotesis sebagai berikut : Diduga perencanaan dan rancang bangun industri roti dapat bekerja efektif dan efisien dalam proses pembuatan roti sesuai dengan yang diinginkan. 


\section{METODELOGI PENELITIAN}

\section{Waktu dan Tempat Penelitian}

Waktu penelitian dimulai pada bulan Maret 2017 sampai selesai, dengan tempat penelitian di Universitas AlGhifari Bandung, Jln. Cisaranten Kulon No.140 Sukarno-Hatta Bandung. Tempat Pelaksanaan Industri Jln. Pahlawan No. 15 Bantaeng-Makasar (Roti Kaffah), dan Jln. Ujung Pandang No. 4 Makassar (Samping Goedang Pops) (Roti LA-KU).

\section{Bahan dan Alat Penelitian}

Bahan yang digunakan mencakup material, instrumentasi dan utilitas. Material yang digunakan adalah stainless steel, baja, besi, dan cat (duco/epoxy). Pada instrumentasi seperti tombol ON/OFF, termokopel, dan lampu indikator. Sedangkan pada utilitas, yang digunakan antara lain: motor listrik, pompa, dudukan motor, pulley, $V$-Belt, pisau, dan engkol.

Alat yang digunakan pada proses pembuatan french fries maker ini, antara lain: mesin potong plat, mesin tekuk plat, gerinda, mesin press, spot welding, bor listrik, tang rivet, solder, spray gun, las listrik, gunting plat, obeng, pengupas kabel, dan kawat las.

\section{Metode Perancangan Mesin}

Pada proses perencanaan dan rancang bangun industri roti ini dilakukan dengan beberapa tahapan antara lain :

\section{Survei Lapangan}

Survei Lapangan dilakukan untuk mengumpulkan data - data alat maupun sumber tentang mesin yang digunakan dalam industri roti yang telah ada. Data yang dikumpulkan meliputi dimensi, prinsip kerja, dan sistem kerja dari alat industri roti yang ada di pasaran serta sistem proses pembuatan roti yang telah ada dilingkungan sekitar atau pesaing.

Analisis Data

Bertujuan untuk menganalisis data-data alat-alat yang telah ada dipasaran berdasarkan kelebihan dan kekurangannya. Data hasil survei di lapangan, adalah proses pembuatan roti di industri kecil menengah masih menempatkan perlatan proses secara sederhana yang berdasarkan pada ketersediaan tempat saja, bukan berdasarkan atas urutan proses dan dimensi peralatan yang digunakan. Perencanaan dan rancang bangun industri roti di buat berdasarkan atas urutan proses pembuatan roti dan pemanfaatan ruang proses sesuai dengan peralatan yang akan digunakan dalam proses pembuatan roti. Berdasarkan analisis di lapangan dapat disimpulkan bahwa untuk mempercepat proses produksi roti dibutuhkan peralatan dengan sistem kerja alat yang mudah dioperasikan serta penataan peralatan industri roti yang sesuai dengan urutan proses pembuatan roti, dengan harga yang relatif lebih murah, proses pembuatan cepat, aman dikonsumsi serta cocok untuk digunakan pada industri kecil.

Perhitungan Perencanaan dan Rancang Bangun Peralatan Industri Roti

Perhitungan yang digunakan dalam pembuatan tugas akhir ini berdasarkan pada peralatan industri roti yang digunakan, termasuk dimensi, fungsi, dan jarak aman yang aman bagi para pekerja, sehingga dapat menghasilkan produk yang aman dikonsumsi oleh konsumen dan nyaman bagi para pegawai untuk bekerja meskipun di lingkungan industri kecil menengah.

Gambar Perencanaan dan Rancang Bangun Yang Dirancang

Langkah awal dari proses perencanaan dan rancang bangun peralatan industri roti ini yaitu diawali dengan menggambar awal perencanaan industri roti skali menengah, rancangan mesin dan peralatan proses yang digunakan, kemudian dilakukan percobaan pelaksanaan proses pembuatan roti sampai dihasilkan perencanaan dan rancang bangun industri roti yang baik, aman, dan nyaman bagi karyawan mau pun oleh konsumen. 
Revisi Gambar

$$
\text { Mengkaji ulang kembali }
$$
rancangan mesin yang telah digambar untuk lebih mempermudah dalam proses perancangan mesin selanjutnya.

Proses Perancangan Keseluruhan

Proses perancangan dan rancang bangum secara keseluruhan dengan merakit komponen-komponen utama menjadi sebuah proses yang direncanakan.

\section{Perakitan Alat Di Workshop}

Setelah perancangan keseluruhan, selanjutnya dilakukan perakitan dengan merakit komponen - komponen utama menjadi sebuah proses yang direncanakan. Uji Coba Alat

Setelah proses selesai diraancang, kemudian dilakukan pengujian terhadap rancangan proses ini dengan tujuan untuk mengetahui apakah rancangan yang dibuat tersebut layak atau tidak layak untuk digunakan.

Proses Receive Dan Reject

Apabila perancangan dan rancang bangun tersebut berfungsi dengan baik maka alur proses industri tersebut layak untuk digunakan, apabila kurang memuaskan dilakukan kembali proses pengujian awal.

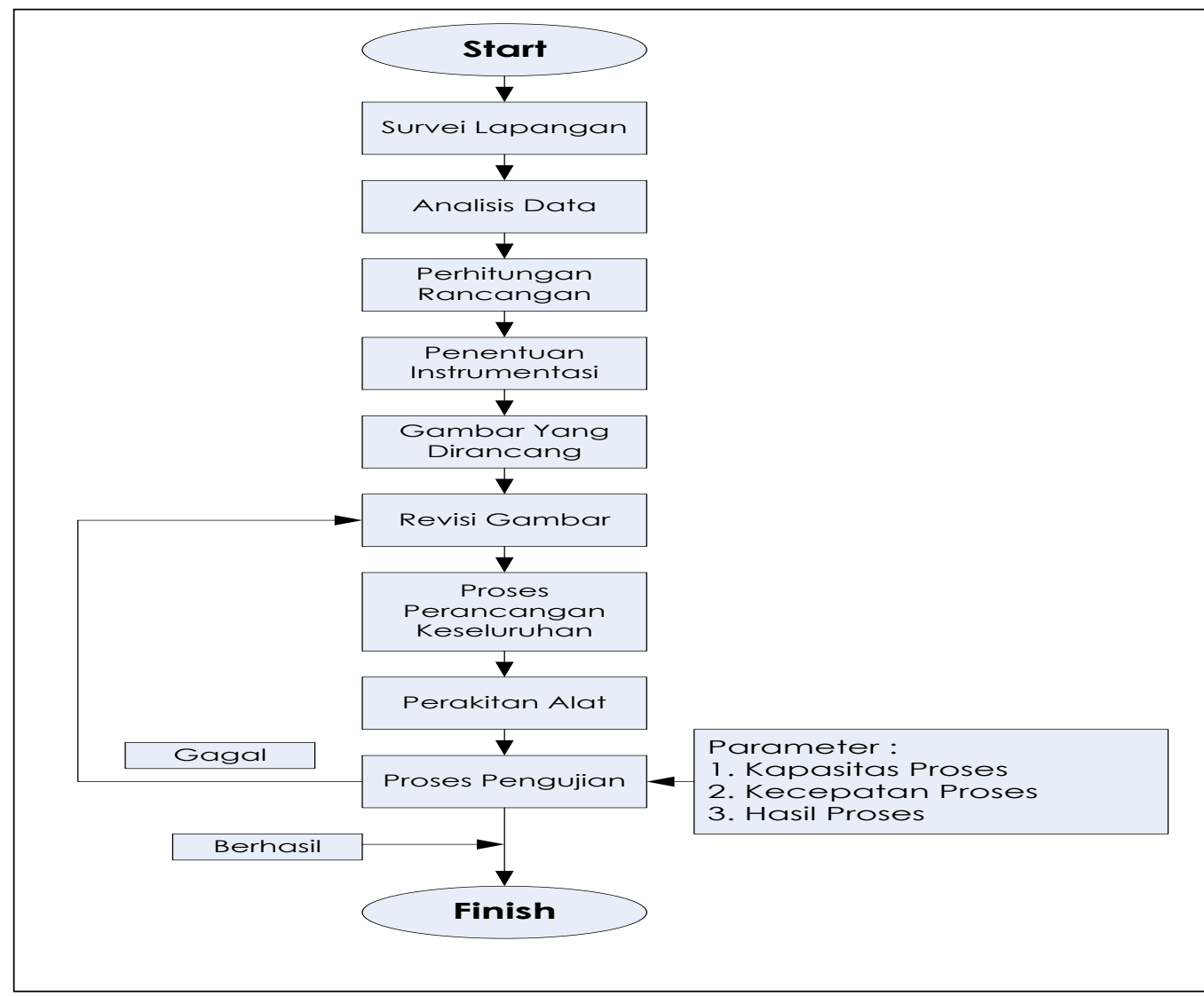

Gambar 1. Diagram Alir Penelitian.

\section{HASIL DAN PEMBAHASAN}

\section{Hasil Penelitian Pendahuluan}

Hasil perencanaan dan rancang bangun industri roti dalam penelitian tugas akhir ini terbagi atas beberapa tahap diantaranya :

1. Indikator Pertumbuhan Industri
Indikator pertumbuhan industri utama yaitu jumlah tenaga kerja dan nilai investasi yang mengalami pergerakan positif. Jumlah total tenaga kerja pada sektor industri makanan pada industri kecil formal dan industri kecil non formal. Berdasarkan data Disperindag Kota Makasar terdapat 46 industri kecil formal 
yang bergerak pada pembuatan roti di Kota Makasar, dimana kapasitas produksi per tahun dan nilai investasi dari industri kecil tersebut bervariasi. Nilai Investasi ini terdiri dari nilai : mesin / peralatan, modal kerja selama 4 bulan meliputi: bahan baku, upah/gaji dan lain-lain (biaya air, listrik, telepon). Industri pangan roti di Kota Makasar bila dikelompokkan berdasarkan interval / range investasi Rp. 50 juta, mayoritas berada pada nilai investasi di bawah Rp. 50 juta berjumlah 36 industri $(78,3 \%)$.

Jika dilihat pengelompokan industri berdasarkan jumlah tenaga kerja menurut definisi Biro Pusat Statistik, industri rumah tangga adalah unit usaha dengan pekerja paling banyak 4 orang termasuk pengusaha, sedangkan industri kecil adalah unit usaha dengan jumlah pekerja paling sedikit 5 orang dan paling banyak 19 orang. Mayoritas industri roti di Kota Makasar adalah industri kecil dengan jumlah tenaga kerja 5 sampai dengan 19 orang sebanyak 31 industri $(67 \%)$ dan sisanya industri rumah tangga dengan jumlah pekerja kurang dari 5 orang sebanyak 8 industri $(17,4 \%)$ dan industri menengah 7 industri $(15,2 \%)$.

Penetapan lokasi produksi perlu mempertimbangkan keadaan dan kondisi lingkungan yang mungkin dapat merupakan sumber pencemaran potensial dan telah mempertimbangkan berbagai tindakan pencegahan yang mungkin dapat dilakukan untuk melindungi pangan yang diproduksinya. Lokasi IKM seharusnya dijaga tetap bersih, bebas dari sampah, bau,asap, kotoran, dan debu. Lingkungan seharusnya selalu dipertahankan dalam keadaan bersih dengan cara-cara sebagai berikut :1) Sampah dibuang dan tidak menumpuk, 2) Tempat sampah selalu tertutup, 3) Jalan dipelihara supaya tidak berdebu dan selokannya berfungsi dengan baik

\section{Bangunan dan fasilitas}

Bangunan dan fasilitas IKM seharusnya menjamin bahwa pangan tidak tercemar oleh bahaya fisik, biologis, dan kimia selama dalam proses produksi serta mudah dibersihkan dan disanitasi. Disain dan tata letak ruang produksi sebaiknya cukup luas, mudah dibersihkan dan tidak digunakan untuk memproduksi produk lain selain pangan. Sebagian besar IKM roti di Kota Makasar kesulitan memenuhi persyaratan terkait bangunan dan fasilitas, mengingat bangunan produksi tidak didesain dari awal untuk produksi pangan yang memenuhi persyaratan GMP namun memanfaatkan bangunan yang sudah ada. Umumnya desain konstruksi sudut pertemuan dinding dengan lantai tidak dibuat landai/ cekung, dinding atau lantai tidak seluruhnya dibuat dari bahan kedap air, rata , halus tetapi tidak licin.

Tata letak di ruang produksi tidak didesain sesuai aliran proses produksi dan mencegah proses kontaminasi. Pintu masuk bahan baku/ karyawan dan pintu keluar produk yang sudah jadi tidak dibuat terpisah. Kondisi lantai masih terdapat yang pecah-pecah sehingga ada celah sebagai sumber kontaminan. Dinding atau pemisah ruangan jarang dibuat dari bahan kedap air, rata, halus, berwarna terang, tahan lama, tidak mudah mengelupas, dan kuat. Tidak semua pintu dan jendela dilengkapi dengan pintu kasa yang dapat dilepas untuk memudahkan pembersihan dan perawatan. Di ruang produksi tidak semua IKM selalu menyediakan tempat untuk mencuci tangan yang selalu dalam keadaan bersih serta dilengkapi dengan sabun dan pengeringnya.

\section{Peralatan produksi}

Tata letak peralatan produksi seharusnya diatur agar tidak terjadi kontaminasi silang. Peralatan produksi yang kontak langsung dengan pangan sebaiknya didesain, dikonstruksi, dan diletakkan sedemikian untuk menjamin mutu dan keamanan pangan yang dihasilkan. Peralatan produksi sebaiknya terbuat dari bahan yang kuat, tahan lama, tidak beracun, mudah dipindahkan atau dibongkar pasang sehingga mudah dibersihkan dan dipelihara serta memudahkan pemantauan dan pengendalian hama. 
Permukaan yang kontak langsung dengan pangan harus halus, tidak bercelah atau berlubang, tidak mengelupas, tidak berkarat dan tidak menyerap air. Alat ukur/timbang seharusnya dipastikan keakuratannya, terutama alat ukur/timbang bahan tambahan pangan (BTP). Sering kali IKM roti tidak cermat meletakkan peralatan proses produksinya sesuai dengan urutan prosesnya sehingga memudahkan bekerja secara higiene, memudahkan pembersihan dan perawatan serta mencegah kontaminasi silang. Misal penempatan peralatan proses produksi yang di dekat jendela yang terbuka tanpa kasa cenderung dapat menyebabkan kontaminsi silang. Tidak semua peralatan dipelihara, diperiksa dan dipantau agar berfungsi dengan baik dan selalu dalam keadaan bersih.

4. Suplai air atau sarana penyediaan air

Sumber air bersih untuk proses produksi sebaiknya cukup dan memenuhi persyaratan kualitas air bersih dan / atau air minum. Air yang digunakan untuk proses produksi harus air bersih dan sebaiknya dalam jumlah yang cukup memenuhi seluruh kebutuhan proses produksi. Umumnya IKM roti Kota Makasar menggunakan suplai air dari PDAM atau dari mata air tanah. Kualitas air yang ada di Bogor relatif tidak bermasalah. PDAM secara rutin melakukan pengujian laboratorium terhadap kualitas air yang disalurkan ke pelanggannya. Pengujian di laboratorium dibutuhkan untuk membuktikan pemenuhan persyaratan kualitas air yang digunakan sesuai standar kualitas air menurut PerMenKes No. 907/MenKes/SK/Per./VII/2002.

5. Fasilitas serta kegiatan higiene dan sanitasi

Fasilitas dan kegiatan higiene dan sanitasi diperlukan untuk menjamin agar bangunan dan peralatan selalu dalam keadaan bersih dan mencegah terjadinya kontaminasi silang dari karyawan. Sarana pembersihan / pencucian bahan pangan, peralatan, perlengkapan dan bangunan (lantai, dinding dan lain-lain sebaiknya tersedia dan terawat dengan baik. Sarana higiene karyawan seperti fasilitas untuk cuci tangan dan toilet / jamban seharusnya tersedia dalam jumlah cukup dan dalam keadaan bersih untuk menjamin kebersihan karyawan guna mencegah kontaminasi terhadap bahan pangan.

Sistem pembuangan limbah seharusnya didesain dan dikonstruksi sehingga dapat mencegah resiko pencemaran pangan dan air bersih. Sarana toilet / jamban seharusnya: a) didesain dan dikonstruksi dengan memperhatikan persyaratan higiene, sumber air yang mengalir dan saluran pembuangan; b) diberi tanda peringatan bahwa setiap karyawan harus mencuci tangan dengan sabun sesudah menggunakan toilet; c) terjaga dalam keadaan bersih dan tertutup; d) mempunyai pintu yang membuka ke arah luar ruang produksi. Pada IKM roti di Kota Makasar masih ada yang belum mempunyai sarana cuci tangan di dekat ruang produksi yang selalu dilengkapi air bersih dan sabun cuci tangan, alat pengering tangan seperti handuk, lap atau kertas serap yang bersih.

\section{Kesehatan dan higiene karyawan}

Kesehatan dan higiene karyawan yang baik dapat menjamin bahwa karyawan yang kontak langsung maupun tidak langsung dengan pangan tidak menjadi sumber pencemaran. Karyawan yang bekerja di bagian pangan harus memenuhi persyaratan sebagai berikut : 1 ) Dalam keadaan sehat, jika sakit atau baru sembuh dari sakit dan diduga masih membawa penyakit tidak diperkenankan masuk ke ruang produksi; 2) Jika menunjukkan gejala atau menderita penyakit menular, misalnya sakit kuning (virus hepatitis A), diare, sakit perut, muntah, demam, sakit tenggorokan, sakit kulit (gatal, kudis, luka, dan lain-lain), keluarnya cairan dari telinga (congek), sakit mata (belekan), dan atau pilek tidak diperkenankan masuk ke ruang produksi.

Karyawan yang menangani pangan harus menutup luka di anggota tubuh 
dengan perban khusus luka Karyawan yang menangani pangan seharusnya mengenakan pakaian kerja yang bersih. Pakaian kerja dapat berupa celemek, penutup kepala, sarung tangan, masker dan / atau sepatu kerja. Namun tidak semua pekerja IKM roti di Kota Makasar selalu patuh menggunakan penutup kepalam sarung tangan. Karyawan tidak selalu mencuci tangan dengan sabun sesudah menangani bahan mentah, atau bahan / alat yang kotor, dan sesudah ke luar dari toilet / jamban. Masih terlihat karyawan yang bekerja makan dan minum, merokok di ruang produksi. Karyawan di bagian pangan ada yang mengenakan perhiasan seperti anting, cincin, gelang, kalung, jam tangan, bros dan peniti atau 64 benda lainnya yang dapat membahayakan keamanan pangan yang diolah. Hal ini sering dilanggar karena kurangnya kesadaran dan pemahaman pekerja.

7. Pemeliharaan dan program higiene dan sanitasi

Pemeliharaan dan program sanitasi terhadap fasilitas produksi (bangunan, mesin /peralatan, pengendalian hama, penanganan limbah dan lainnya) dilakukan secara berkala untuk menjamin terhindarnya kontaminasi silang terhadap pangan yang diolah. Program higiene dan sanitasi seharusnya menjamin semua bagian dari tempat produksi telah bersih, termasuk pencucian alat-alat pembersih.

Program higiene dan sanitasi seharusnya dilakukan secara berkala serta dipantau ketepatan dan keefektifannya dan jika perlu dilakukan pencatatan. Pengendalian hama dilakukan untuk mengurangi kemungkinan masuknya hama ke ruang produksi yang akan mencemari pangan. Belum seluruhnya IKM mempunyai jendela, pintu dan lubang ventilasi yang telah dilapisi dengan kawat kasa untuk menghindari masuknya hama serta menutup lubang dan selokan yang memungkinkan masuknya hama. Mengingat lokasi produksi IKM roti umumnya menjadi satu dengan lokasi tempat tinggal, maka masih memungkinkan ditemui adanya hewan peliharaan seperti anjing, kucing, ayam dan burung berkeliaran di sekitar/ di dalam ruang produksi.

\section{Penyimpanan}

Penyimpanan bahan yang digunakan dalam proses produksi (bahan baku, bahan penolong, BTP) dan produk akhir dilakukan dengan baik sehingga tidak mengakibatkan penurunan mutu dan keamanan pangan.

Penyimpanan bahan dan produk akhir harus disimpan terpisah dalam ruangan yang bersih, sesuai dengan suhu penyimpanan, bebas hama, penerangannya cukup. Penyimpanan bahan baku tidak boleh menyentuh lantai, menempel ke dinding maupun langitlangit. Penyimpanan bahan dan produk akhir harus diberi tanda dan menggunakan sistem First In First Out (FIFO) dan sistem First Expired First Out (FEFO), yaitu bahan yang lebih dahulu masuk dan / atau memilki tanggal kedaluwarsa lebih awal harus digunakan terlebih dahulu dan produk akhir yang lebih dahulu diproduksi harus digunakan / diedarkan terlebih dahulu. Bahan-bahan yang mudah menyerap air harus disimpan ditempat kering, misalnya garam, gula, dan rempah-rempah bubuk. Bahan berbahaya seperti sabun pembersih, bahan sanitasi, racun serangga, umpan tikus, dan lain-lain harus disimpan dalam ruang tersendiri dan diawasi agar tidak mencemari pangan. Bahan pengemas harus disimpan terpisah dari bahan baku dan produk akhir. Label pangan harus disimpan di tempat yang bersih dan jauh dari pencemaran. Penyimpanan mesin / peralatan produksi yang telah dibersihkan tetapi belum digunakan harus di tempat bersih dan dalam kondisi baik, sebaiknya permukaan peralatan menghadap ke bawah, supaya terlindung dari debu, kotoran atau pencemaran lainnya.

\section{Pengendalian proses}

Pengendalian proses produksi pangan dapat dilakukan dengan cara 
sebagai berikut : a) Penetapan spesifikasi bahan; b) Penetapan komposisi dan formulasi bahan; c) Penetapan cara produksi yang baku ; d) Penetapan jenis, ukuran, dan spesifikasi kemasan; e) Penetapan keterangan lengkap tentang produk yang akan dihasilkan termasuk nama produk, tanggal produksi, tanggal kadaluwarsa.

Bahan yang digunakan seharusnya dituangkan dalam bentuk formula dasar yang menyebutkan jenis dan persyaratan mutu bahan. Jika menggunakan bahan tambahan pangan (BTP), harus menggunakan BTP yang diizinkan sesuai batas maksimum penggunaannya. Air yang merupakan bagian dari pangan maupun yang kontak dengan bahan pangan seharusnya memenuhi persyaratan air minum atau air bersih sesuai peraturan perundangundangan. IKM harus membuat bagan alir atau urut-urutan proses secara jelas kondisi baku dari setiap tahap proses produksi, seperti misalnya berapa menit lama pengadukan, berapa suhu pemanasan dan berapa lama bahan dipanaskan.

\section{Pelabelan pangan}

Kemasan pangan diberi label yang jelas dan informatif untuk memudahkan konsumen dalam memilih, menangani, menyimpan, mengolah dan mengonsumsi pangan IRT. Label pangan IRT tidak boleh mencantumkan klaim kesehatan atau klaim gizi. Label pangan IKM belum seluruhnya telah memuat sekurang-kurangnya hal berikut yang dipersyaratkan: a) Nama produk sesuai dengan jenis pangan IRT yang ada di Peraturan Kepala Badan POM HK.03.1.23.04.12.2205 Tahun 2012 tentang Pemberian Sertifikat Produksi Pangan Industri Rumah Tangga. b) Daftar bahan atau komposisi yang digunakan c) Berat bersih atau isi bersih d) Nama dan alamat IRTP e) Tanggal, bulan dan tahun kedaluwarsa f) Kode produksi g) Nomor P-IRT.
11. Pengawasan oleh penanggungjawab Penanggung jawab minimal harus mempunyai pengetahuan tentang prinsipprinsip dan praktek higiene dan sanitasi pangan serta proses produksi pangan yang ditanganinya dengan pembuktian kepemilikan Sertifikat Penyuluhan Keamanan Pangan (Sertifikat PKP).

\section{Penarikan produk}

Pemilik IRTP harus menarik produk pangan dari peredaran jika diduga menimbulkan penyakit / keracunan pangan dan / atau tidak memenuhi persyaratan 67 peraturan perundangundangan di bidang pangan. Penanggung jawab IRTP mempersiapkan prosedur penarikan produk pangan.

\section{Pencatatan dan dokumentasi}

Pemilik seharusnya mencatat dan mendokumentasikan : 1) Penerimaan bahan baku, bahan tambahan pangan (BTP), dan bahan penolong sekurangkurangnya memuat nama bahan, jumlah, tanggal pembelian, nama dan alamat pemasok; 2) Produk akhir sekurangkurangnya memuat nama jenis produk, tanggal produksi, kode produksi, jumlah produksi dan tempat distribusi / penjualan; 3) Penyimpanan, pembersihan dan sanitasi, pengendalian hama, kesehatan karyawan, pelatihan, distribusi dan penarikan produk dan lainnya yang dianggap penting. Catatan dan dokumen dapat disimpan selama 2 (dua) kali umur simpan produk pangan yang dihasilkan. Catatan dan dokumen yang ada sebaiknya dijaga agar tetap akurat dan mutakhir. Pada umumnya IKM mempunyai kelemahan dalam dokumentasi karena terbatasnya tenaga kerja serta waktu yang tersedia, kurangnya disiplin dalam pencatatan.

\section{Pelatihan karyawan}

Pemilik / penanggung jawab harus sudah pernah mengikuti penyuluhan tentang Cara Produksi Pangan Yang Baik untuk Industri Rumah Tangga (CPPBIRT)/. Pemilik / 
penanggung jawab tersebut harus menerapkannya serta mengajarkan pengetahuan dan ketrampilannya kepada karyawan yang lain. Pada umumnya IKM mempunyai kelemahan dalam kegiatan pelatihan tenaga kerja karena terbatasnya dana, kemampuan serta waktu yang tersedia. IKM cenderung menggunakan fasilitas pelatihan yang diselenggarakan oleh pemerintah secara cuma-cuma.

Survey lapangan dan analisis data mengenai industri roti di kota Makasar telah dilakukan sehingga dapat diambil kesimpulan bahwa perkembangan industri roti di kota Makasar mengalami peningkatan hanya dari segi sanitasi dan higienisasi bahan baku, proses pengolahan dan karyawan masih kurang sehingga

diperlukan perencanaan dan rancang bangun bangun industri roti yang aman bagi karyawann dan konsumen.

\section{Penelitian Utama}

Penelitian utama tugas akhir ini melalui beberapa tahap rancangan, yaitu :

1. Perancangan flowsheet proses
Perancangan flowsheet proses pengolahan roti dapat diliat pada gambar 4 Perancangan di buat berdasarkan pada proses pegolahan roti dari mulai tahap bahan baku dsampai produk akhir yaitu roti. Perancangan flowsheet menyesuaikan dengan ukuran mesin yang dipakai dalam proses pengolahan roti.

\section{Perancangan tata letak}

Perancangan tata letak industri roti harus sesuai dengan alur proses sehingga dalam menjaga higienis bahan baku hingga produk terjamin keamanannya. Tata letak proses pengolahan dapat dilihat pada gambar 5 . Tata letak alat harus berdasarkan pada kapasitas mesin, kecepatan proses dan hasil produk roti yang terjamin keamanannya. Selain itu keamanan dan kenyamanan karyawan harus menjadi pertimbangan sehingga pengawasan dapat dilakukan dengan baik. Peralatan yang dipakai dalam industri roti ini terdiri atas beberapa peralatan utama yaitu mixing, proofing, oven dan bread slicer seperti pada gambar 2.

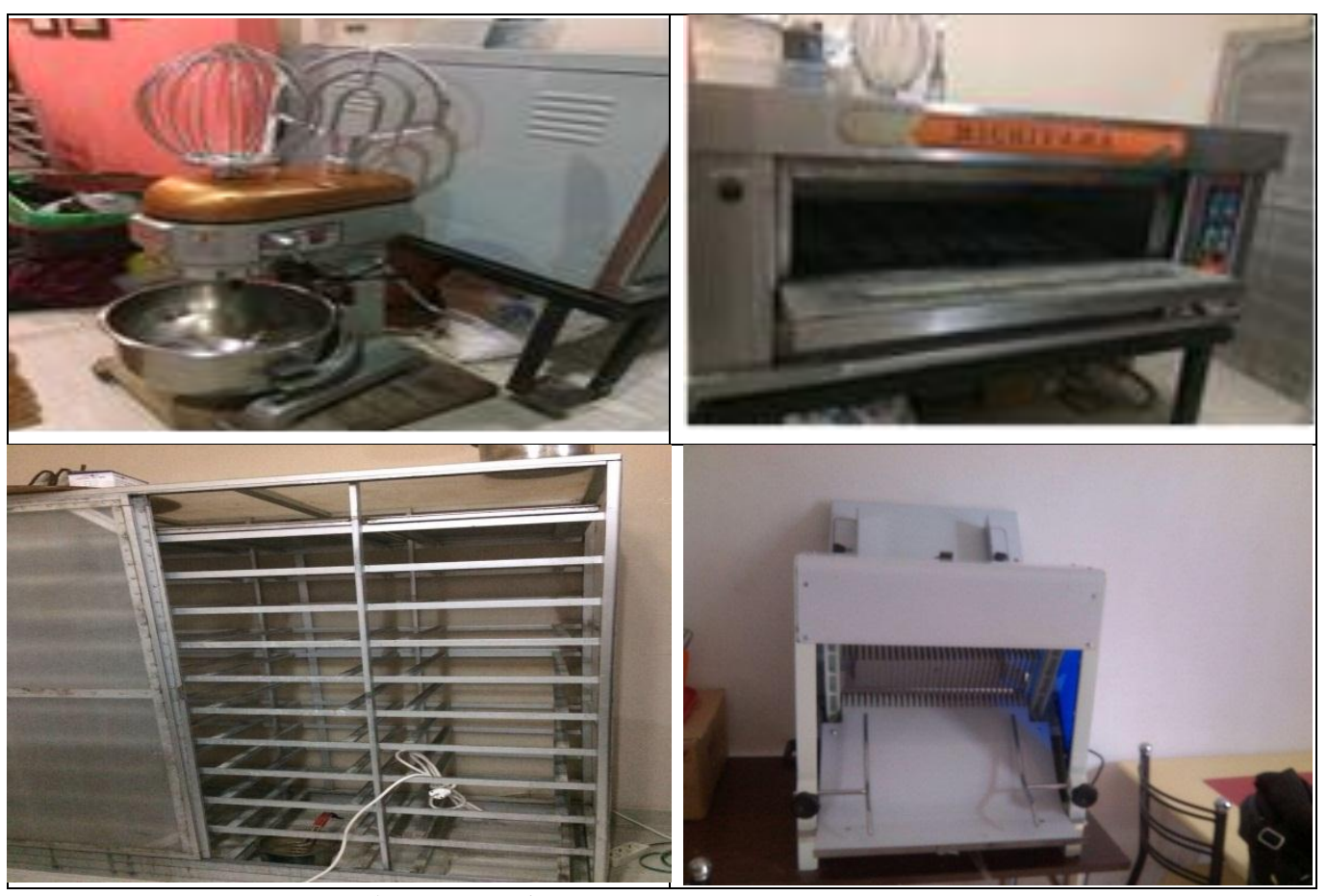

Gambar 2. Peralatan utama proses pengolahan roti.

Perencanaan Industri Roti Kaffah di Kabupaten Bantaeng, Sulawesi Selatan 
3. Hasil perancangan dan rancang bangun industri roti

Hasil perancangan dan rancang bangun ini dapat dilihat pada gambar 6 . Mutu atau kualitas roti yang dihasilkan oleh UKM sangat dipengaruhi oleh efisiensi serta kehigienis-an mesin/peralatan yang digunakan, oleh karenanya pemahaman dari pihak UKM
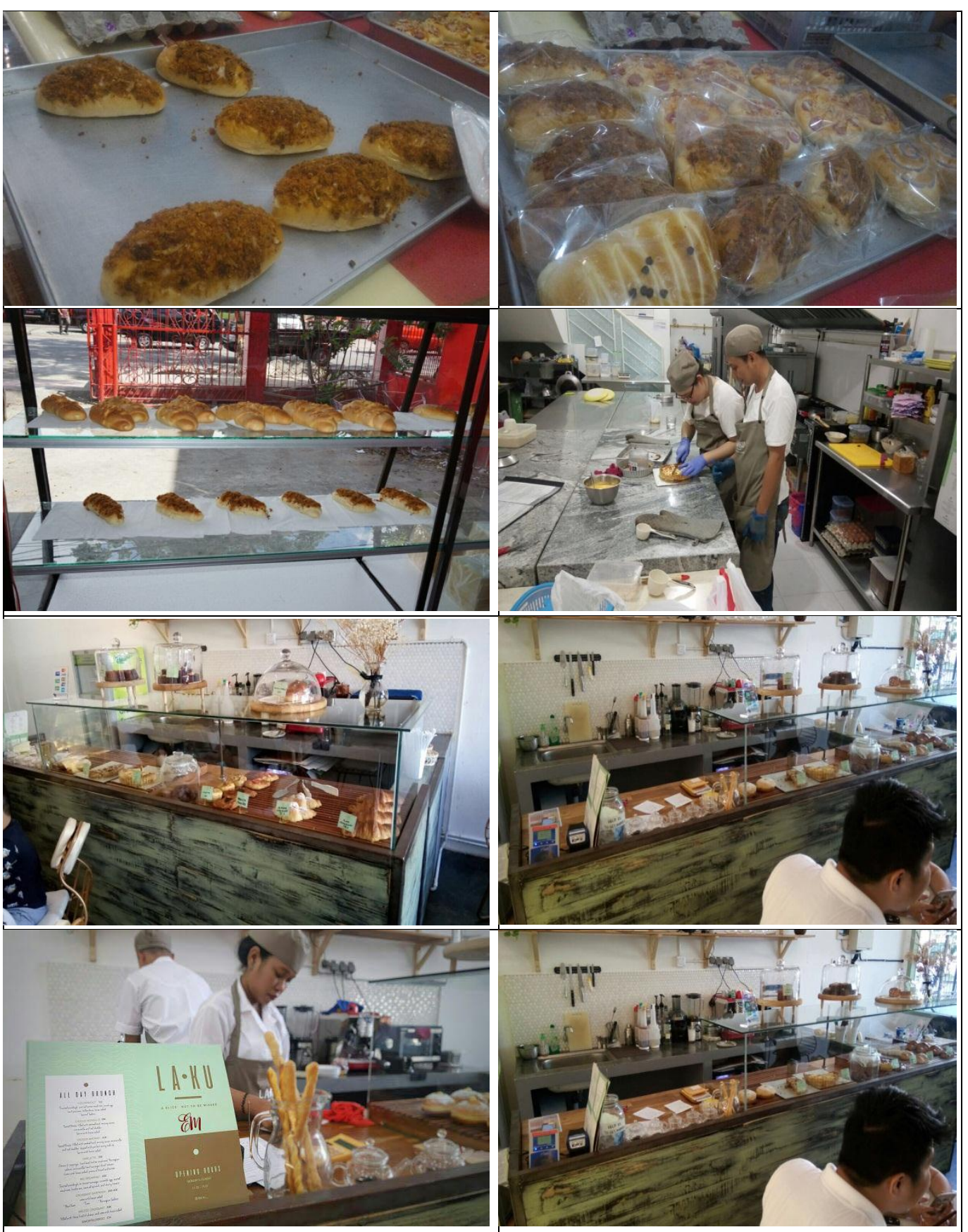

terhadap konsep GMP, SOP dan HACCP sangat menunjang keberlangsungan produksi di UKM tersebut serta menjaga keamanan pangan produk yang dikonsumsi oleh masyarakat. Beberapa perbaikan di industri roti dimulai dari sanitasi tempat, higienis produk dan karyawan dapat dilihat dalam gambar 3 .

Perencanaan Industri Roti Kaffah di Kabupaten Bantaeng, Sulawesi Selatan 


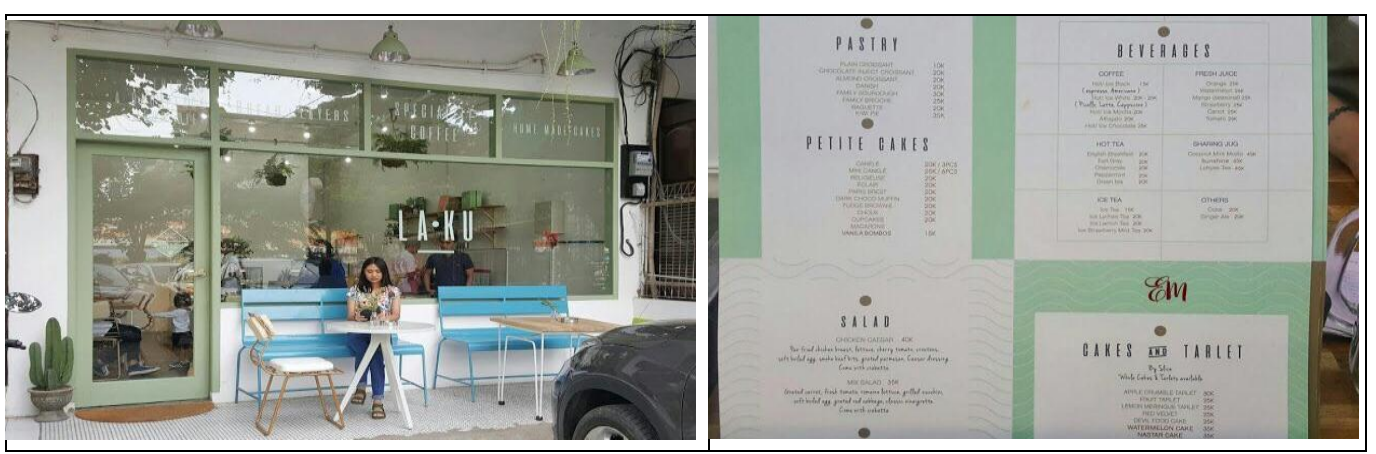

Gambar 3. Perbaikan industri roti.

Melalui perencanaan dan rancang bangun pada proses produksi roti dan beberapa mesin/peralatan, diharapkan mampu meningkatkan kualitas produk, efisiensi produksi serta keamanan pangan. Selain itu juga dengan adanya SOP tersebut diharapkan akan memudahkan tahapan kerja para pekerja pabrik dan menstandarkan tahap operasional mesin/peralatan serta menghindari kerusakan dini pada peralatan tersebut. Perencanaan perbaikan layout mesin/peralatan yang bisa digunakan sebagai acuan perbaikan penyusunan tata letak mesin/peralatan dimasa mendatang, agar dihasilkan waktu produksi yang seefisien mungkin.

\section{KESIMPULAN DAN SARAN}

\section{Kesimpulan}

Setelah dilakukan proses perencanaan dan rancang bangun industri roti ini dapat disimpulkan sebagai berikut :

1. Perencanaan flowsheet proses berpengaruh terhadap penggunaan maksimal kapasitas mesin, kecepatan proses pengolahan dan hasil produk yang lebih terjamin keamanannya.

2. Perancangan tata letak proses pengolahan juga berpengaruh terhadap penggunaan maksimal kapasitas mesin, kecepatan proses pengolahan dan hasil produk yang lebih terjamin keamanannya.

3. Berdasarkan hasil pengujian produk yang dihasilkan lebih cepat dan aman serta pengawasan mudah dilakukan.

\section{Saran}

Saran yang dapat penulis berikan dalam penulisan tugas akhir ini sebagai berikut :

1. Sebaiknya menggunakan material yang anti toksik dan anti korosi karena bila sembarangan memakai material ditakutkan akan mempengaruhi hasil proses yang diharapkan.

2. Perlunya dilakukan modifikasi pada mesin sehingga dihasilkan produk yang lebih maksimal.

\section{DAFTAR PUSTAKA}

Anonim. 1981. Pedoman Pembuatan Roti dan Kue. Djambatan: Jakarta.

Buckle, K, A. 1987. Ilmu Pangan, Penerjemah Harry Purnomo. UI Press:Jakarta.

Desrosier N. W., and Tressler D. K.. 1977. Fundamentals of Food Freezing, The AVI Publ. Co. Inc. Westport Connecticut. USA.

Ditjen POM, 1996. Pedoman Penerapan Cara Produksi Pangan Yang Baik (CPPB). Departemen Kesehatan. [Ditjen POM] Ditjen Pengawasan Obat dan Makanan. Jakarta

Hardinsyah dan Leily Amalia. 2007.

Perkembangan Konsumsi Terigu

Dan Pangan Olahannya Di Indonesia 1993-2005 (Trend of Wheat Flour and Its Processe

Product Consumption in Indonesia. Jurnal Giri dan Pangan.

Hariyadi P. 2007. Upaya Peningkatan

Keamanan, Mutu, dan Gizi Pangan melalui Ilmu dan 
Teknologi Pangan. Southeast Asian Food Science and Technology (SEAFAST) Center IPB. Bogor.

Norman, W.D. 1988. Teknologi Pengawetan Pangan: Penerbit Universitas Indonesiajakarta.

Ong Kevin Gunawan dan Ratih Indriyani, 2015. Analisa Strategi Bersaing Pada Bakery Donalson Di Makassar Program Manajemen Bisnis, Program Studi Manajemen. Universitas Kristen Petra.

Pedoman Umum HACCP (Hazard Analysis Critical Control Point). Jakarta : Ditjen POM, Departemen Kesehatan. [Ditjen PDN] Ditjen Perdagangan Dalam Negeri. 1999. Undang-Undang RI No. 8 Tahun 1999 tentang Perlindungan Konsumen. Jakarta : Ditjen, PDN, Departemen Perindustrian dan Perdagangan.

Pelczar, M.J. $1988 . \quad$ Dasar-dasar Mikrobiologi. Penerbit Universitas Indonesia: Jakarta.

Winarno. 1995. Kimia Pangan dan Gizi, Cetakan ke- tujuh, PT. Gramedia Pustaka Utama: Jakata.

Wiyono. 1980. Struktur Anatomi Gandum, Fakultas Pertanian Unibraw, Malang.

Yudhatama, R. 2014. Pertumbuhan Ekonomi Makassar di Atas Sembilan Persen. Antaranews. Retrieved March 3, 2014 from http://makassar. Agora Vol. 3, No. 2, (2015). 